\title{
Removal of cadmium $\mathrm{Cd}(\mathrm{ii})$ and silver $\mathrm{Ag}(\mathrm{i})$ from aqueous solutions by nano activated alumina. part i: batch adsorption experiments
}

\author{
Alaa Wadie $^{1, *}$, and Enas Al-Khawaja ${ }^{2}$ \\ ${ }^{1}$ College of Engineering, Babylon University, Hilla, Iraq \\ ${ }^{2}$ Najaf Directorate for Health, Najaf, Iraq
}

\begin{abstract}
The extent of removal of heavy metal ions cadmium $\mathrm{Cd}(\mathrm{II})$ and silver $\mathrm{Ag}(\mathrm{I})$ in single and binary system by adsorption on alumina has been investigated. Adsorption experiments were performed in batch technique from synthetic solutions using high purity nano activated alumina prepared in laboratory as adsorbent for heavy metals remove. Several experimental parameters that affect the extent of adsorption of the metal ions of interest have been investigated such as adsorbent dosage, concentration of the adsorbate, contact time, agitation speed and $\mathrm{pH}$ of the system under study. The equilibrium nature of the adsorption of the metal ions at different concentrations has been followed by Freundlich and Langmuir adsorption isotherms. Correlation coefficients $\left(R^{2}\right)$ derived from these plots are (0.965) for cadmium $\mathrm{Cd}(\mathrm{II})$ and (0.966) for silver $\mathrm{Ag}(\mathrm{I})$. This work proposes a cost-effective method for the efficient removal of $\mathrm{Cd}(\mathrm{II})$ and $\mathrm{Ag}(\mathrm{I})$ from aqueous solutions. The conditions required for effective removal have been optimized.
\end{abstract}

\section{Introduction}

Water pollution due to the disposal of industrial effluents enriched with toxic metallic species is a matter of concern [1]. The metals, namely chromium, cadmium, arsenic, nickel, zinc, copper, lead and mercury, are regularly used in various industries. Furthermore, these heavy metals are non-biodegradable and exist for a long time in the environment. They have a tendency to enter into living tissues. These metals are reported to be harmful even at low concentrations. Thus, industrial effluents must be treated prior to their discharge into water resources [2].

Alumina $\left(\mathrm{Al}_{2} \mathrm{O}_{3}\right)$ is a fine white powder which resembles common salt [3]. Activated alumina is manufactured from aluminum hydroxide in a way that produces a highly porous material; this material can have a surface area significantly over $200 \mathrm{~m}^{2} / \mathrm{gm}$. The compound is used as a desiccant (to keep things dry by absorbing water from the air) and as a filter of fluoride, arsenic and selenium in drinking water. It is made of aluminum oxide (alumina, $\mathrm{Al}_{2} \mathrm{O}_{3}$ ), the same chemical substance as sapphire and ruby (but without the impurities that give those gems their color). It has a very high surface-area-to-weight ratio, due to the many "tunnel like" pores that it has [4].

Various technologies such as ion exchange, reverse osmosis, electrolytic removal, reduction, adsorption, precipitation, membrane filtration and flocculation have been reported for the removal of heavy metals from industrial effluents. But these technologies have some disadvantages such as high operational and maintenance cost, expensive equipment, incomplete metal removal, high energy requirement and generation of toxic residual metal sludge. Disposal of toxic sludge is another major problem in most methodologies [2].

The presence of heavy metals in wastewater will contaminate the water environment.

*Corresponding Author: Eng.alaa.husaeen@uobabylon.edu.iq 
Furthermore, the wastewater which has not been handled properly will pose an admitted hazard to human health and the environment. Hence, heavy metals must be removed from wastewater to bring their concentrations down to below the prescribed legal limit [5].

Nowadays the importance of nanoparticles and their uses in different industries have attracted many researches. The materials in nano-scale show different characteristics in comparison with their bulk state. Nano-materials have potential applications in optoelectronics, catalysis, and membranes. In this paper Nanosize $\gamma$-alumina was successfully synthesized by sol-gel method [6].

\section{Materials and methods}

\subsection{Material}

Cadmium nitrate $\left(\mathrm{Cd}\left(\mathrm{NO}_{3}\right)_{2}\right)$ and silver nitrate $\mathrm{AgNO}_{3}$ were used for preparing synthetic solutions of heavy metal ions in the required concentration. Alumina $\left(\mathrm{Al}_{2} \mathrm{O}_{3}\right)$ of $99.9 \%$ prepared in laboratory was used as the adsorbent for the study. $\quad \mathrm{Al}\left(\mathrm{NO}_{3}\right)_{3} \cdot 9 \mathrm{H}_{2} \mathrm{O}(46.9 \mathrm{~g})$ was dissolved in $125 \mathrm{~mL}$ deionized water and 125 $\mathrm{mL}$ ethanol. then add glucose surfactant. Under continues magnetic stirring added a drop of ammonium hydroxide untie the solution mixture was turn to gel and then filtered to remove any insoluble impurity. The gel was draying at $110^{\circ} \mathrm{C}$ for around $12 \mathrm{~h}$. The $\mathrm{pH}$ of the solution mixture was initially 2 . As the reaction proceeds the $\mathrm{pH}$ gradually increased and rose sharply from 2 to 5 producing alumina gel. The draying gel was heated for $2 \mathrm{~h}$ at $700^{\circ} \mathrm{C}$.

\subsection{Batch adsorption experiments}

A definite volume of heavy metal ion stock solution with a known initial concentration was stirred with a definite amount of activated alumina for the stipulated time at a fixed temperature in a mechanical shaker. The unadsorbed heavy metal ions which remained in solution were filtered and the amount of heavy metal ions was estimated after attainment of equilibrium. The extent of retention of the different metal ions by alumina was studied by varying several parameters such as the initial concentration of adsorbate $(50,100,150$ and 200) $\mathrm{mg} / \mathrm{L}$, adsorbent dosages $(0.1,0.5,1,1.5$ and 2) $\mathrm{g}$, solution temperature $\left(25^{\circ} \mathrm{C}\right), \mathrm{pH}(3.5$, $5,6.5,8$ and 9.5) and contact time $(20,30,60$, 120 and 180) min.. Freundlich and Langmuir isotherms were also studied for varying concentrations of the different metal ions at constant temperature.

\section{Results and discussion}

\subsection{Equilibrium Time}

For batch experiments, the contact time should be fixed at value ensure reaching equilibrium concentrations. Figures (1,2 and 3) show the effect of contact time on $\mathrm{Cd}^{+2}$ and $\mathrm{Ag}^{+1}$ removal using $1.5 \mathrm{gm}$ of alumina added to $100 \mathrm{~mL}$ of metal solution for batch tests at $25^{\circ} \mathrm{C}$. These figures demonstrate that $\mathrm{Cd}^{+2}$ and $\mathrm{Ag}^{+1}$ removal percentage significantly increased with an increase in contact time. It is clear that the sorption rate was rapid at the initial stage and gradually slowed down afterwards. The slower sorption was likely due to the decrease in sorption sites on the surface of the alumina. About $98.6 \% \mathrm{Cd}^{+2}$ were removed in $120 \mathrm{~min}$; while $99 \% \mathrm{Ag}^{+1}$ were removed in $60 \mathrm{~min}$ for single system. While $98 \%$ of $\mathrm{Cd}^{+2}$ and $97 \%$ of $\mathrm{Ag}^{+1}$ was removed in 60 min for binary system. The kinetic data show that $\mathrm{Cd}^{+2}$ and $\mathrm{Ag}^{+1}$ removal mainly occurred within 120 and $60 \mathrm{~min}$, respectively.

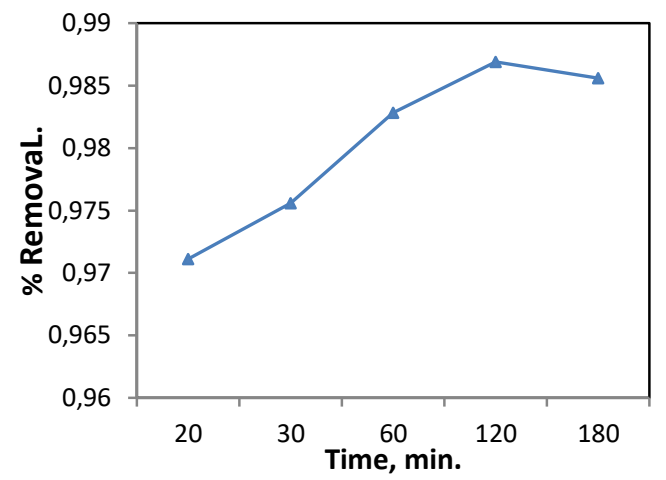

Fig. 1. Removal efficiency of cadmium $\mathrm{Cd}^{+2}$ on nano activated alumina as a function of contact time, $\left(\mathrm{C}_{0}=50 \mathrm{mg} / \mathrm{L} ; \mathrm{pH}=6.5 ;\right.$ dose=1.5 gm; agitation speed $=250 \mathrm{rpm}$ ). 


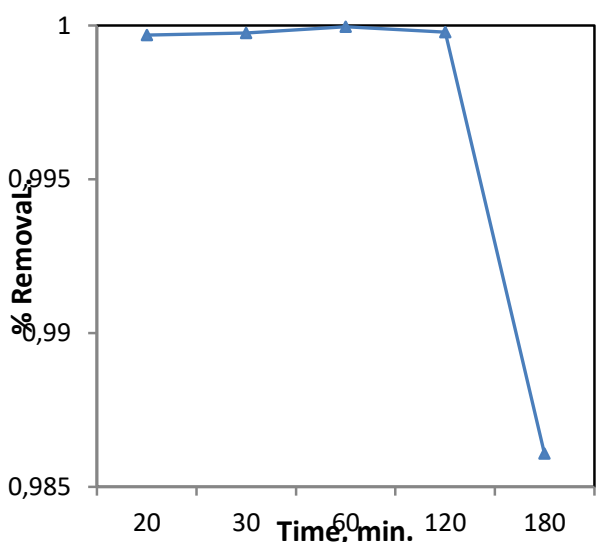

Fig. 2. Removal efficiency of silver $\mathrm{Ag}^{+1}$ on nano activated alumina as a function of contact time $\left(\mathrm{C}_{0}=50 \mathrm{mg} / \mathrm{L} ; \mathrm{pH}=6.5\right.$; dose=1.5 gm; agitation speed $=250 \mathrm{rpm}$ ).

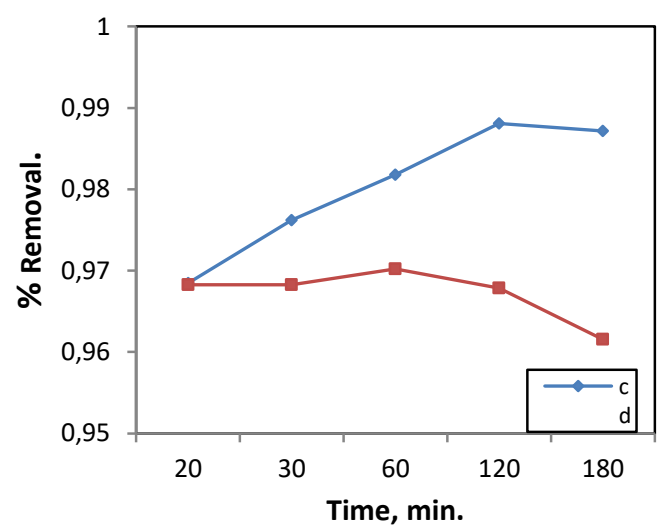

Fig. 3. Removal efficiency of binary system cadmium and silver on alumina as a function of contact time $\left(\mathrm{C}_{0}=50 \mathrm{mg} / \mathrm{L} ; \mathrm{pH}=6.5 ;\right.$ dose $=1.5$ gm; agitation speed $=250 \mathrm{rpm}$ ).

\subsection{Initial pH of the solution}

The solution $\mathrm{pH}$ is an important parameter which influences most of the solid/liquid sorption processes. The sorption of $\mathrm{Cd}^{+2}$ and $\mathrm{Ag}^{+1}$ on the alumina was examined at different $\mathrm{pH}$ ranging from 3.5 to 9.5 with an initial metal concentration of $50 \mathrm{mg} / \mathrm{L}$ as shown in Figures (4, 5 and 6).

The affinity of sorption is generally determined by $\mathrm{pH}$ at point of zero charge $\mathrm{pH}_{\mathrm{PZC}}$. The $\mathrm{pH}_{\mathrm{PZC}}$ is the $\mathrm{pH}$ at which a positive charge by protonation exists in approximately equal numbers with negative charges caused by the development of deprotonation on the alumina surface. Under an acidic condition or $\mathrm{pH}$ below $\mathrm{pH}$ PZC, protons are sorbed on the functional group that causes the alumina surface to have a net positive charge and, thus, inhibit cation sorption. At above pHpzc, the oxygen atom stays deprotonized and the surface prevails to have a net negative charge, thus, enhancing cation sorption [7].

At $\mathrm{pH}<\mathrm{pHpzc}=6.5$ (Figures 4 to 6$)$, the surfaces of $\mathrm{AL}_{2} \mathrm{O}_{3}$ having a net positive charge hinder the $\mathrm{Cd}^{+2}$ ion adsorption due to the electrostatic repulsion. Also, stiff competitions between $\mathrm{H}^{+}$and $\mathrm{Cd}^{+2}$ ion for the active sites will also decrease the $\mathrm{Cd}^{+2}$ ion adsorption. At $\mathrm{pH}>$ pHpzc, hydroxyl groups were progressively deprotonated and a net negative charge was presented on the surfaces of $\mathrm{AL}_{2} \mathrm{O}_{3}$, which contributed to the $\mathrm{Cd}^{+2}$ ion adsorption through the formation of metal - ligand composite complexes with cationic $\mathrm{Cd}^{+2}$ ion .

Over the $\mathrm{pH}$ range from 8-9.5, the adsorption capacity of $\mathrm{Cd}^{+2}$ ion increased from 0.965 to $0.99 \mathrm{mg} / \mathrm{gm}$, which was attributed to the critical $\mathrm{pH}$ value for $\mathrm{Cd}^{+2}$ ion hydrolysis formation of $\mathrm{Cd}(\mathrm{OH})^{+}$and $\mathrm{Cd}_{2}(\mathrm{OH})_{3}^{+}$and precipitation $\left(\mathrm{Cd}(\mathrm{OH})_{2} \geq 8\right)$ through the electrostatic interaction and deposition, [Jie, et al., 2015]. Meanwhile, the electrostatic attraction between the pairs of electrons on the oxygen atoms of alumina and the positive cationic $\mathrm{Cd}^{+2}$ ion also facilitated the adsorption of $\mathrm{Cd}^{+2}$ ion. Moreover, surface precipitation and complexation between the carboxylic group, hydroxyl and $\mathrm{Cd}^{+2}$ ion also contributed to the adsorption of $\mathrm{Cd}^{+2}$ ion. Finally, the physical property of the $\mathrm{AL}_{2} \mathrm{O}_{3}$ and the Vander vales interactions occurring between the hexagonally arrayed carbon atoms in the $\mathrm{Cd}^{+2}$ ion could also conduce to the adsorption of $\mathrm{Cd}^{+2}$ ion [8].

The experimental results showed that $\mathrm{Cd}^{+2}$ and $\mathrm{Ag}^{+1}$ can be removed at different $\mathrm{pH}$ values. It is clear from figures mentioned above that the time required to reach equilibrium in batch systems is equal to 120 and $60 \mathrm{~min}$ for $\mathrm{Cd}^{+2}$ and $\mathrm{Ag}^{+1}$, respectively, although the initial $\mathrm{pH}$ of the solution was varied from 3.5 to 9.5 . Also, the maximum removal efficiency of these metals was achieved at initial $\mathrm{pH}$ of 6.5 . 


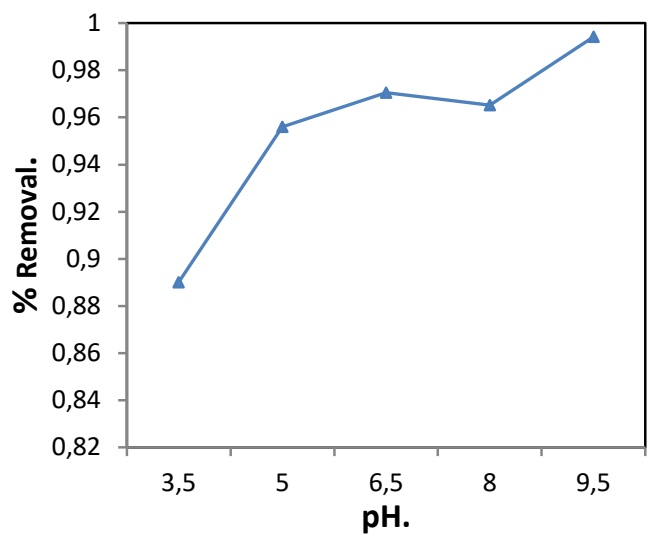

Fig. 4. Removal efficiency of $\mathrm{Cd}^{+2}$ ions on alumina at different $\mathrm{pH}$ solution; Reaction conditions: $(\mathrm{Co}=50 \mathrm{mg} / \mathrm{L}, \quad$ dose $=1.5 \mathrm{gm}$, agitation speed $=250 \mathrm{rpm}$, time $=180 \mathrm{~min}$ ).

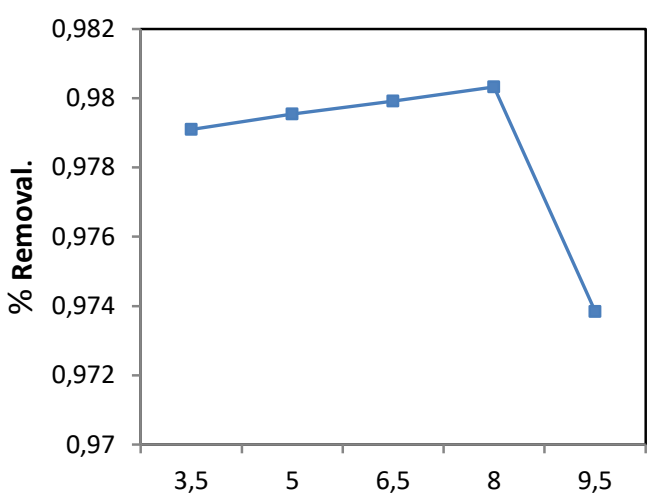

Fig. 5. Removal efficiency of $\mathrm{Ag}^{+1}$ ions on alumina at different $\mathrm{pH}$ solution; Reaction conditions: $(\mathrm{Co}=50 \mathrm{mg} / \mathrm{L}$, dose $=1.5 \mathrm{gm}$, agitation speed $=250 \mathrm{rpm}$, time $=180 \mathrm{~min})$.

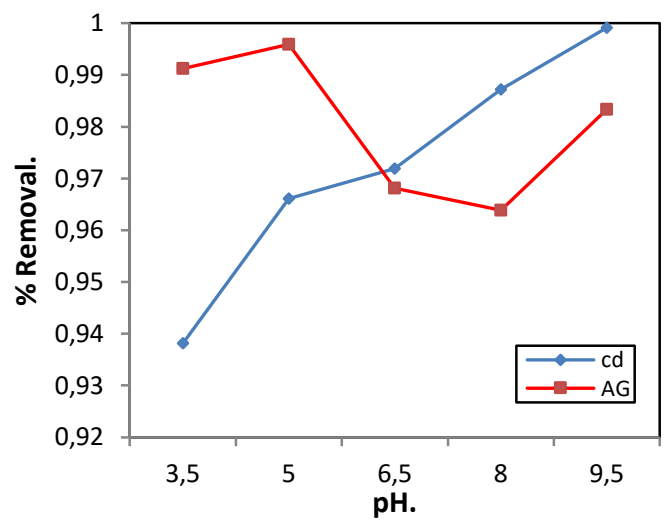

Fig. 6. Removal efficiency of binary system at different $\mathrm{pH}$ solution; Reaction conditions: $(\mathrm{Co}=50 \mathrm{mg} / \mathrm{L}$, dose $=1.5 \mathrm{gm}$, $250 \mathrm{rpm}$, time $180 \mathrm{~min})$.

\subsection{Optimizing alumina weight}

Figures (7, 8, and 9) present the $\mathrm{Cd}^{+2}$ and $\mathrm{Ag}^{+1}$ removal efficiencies as a function of different amounts of alumina. It can be observed that removal efficiency improved with increasing adsorbent dosage from $0.1 \mathrm{gm}$ to $2 \mathrm{gm}$ for $\mathrm{Cd}^{+2}$ and $\mathrm{Ag}^{+1}$ at a fixed initial metal concentration. This was expected due to the fact that the higher dose of sorbents in the solution, the greater availability of sorption sites. This means that the more alumina particles are able to provide more alumina surface-active sites for collision with metal molecules to accelerate the metal removal efficiencies.

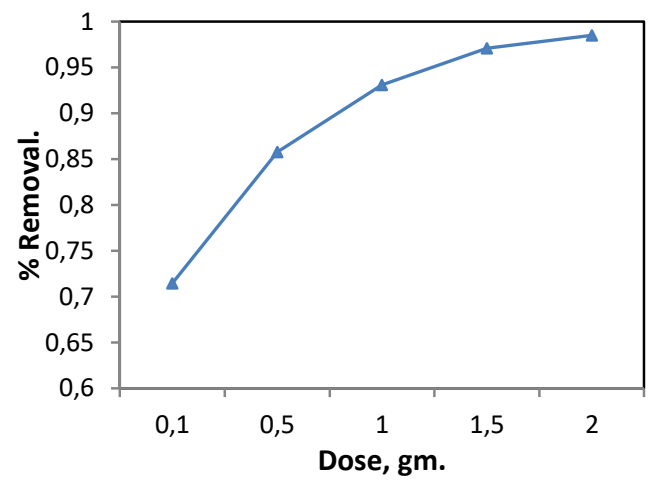

Fig. 7. Effect of alumina dosage on removal efficiencies of $\mathrm{Cd}^{+2}(\mathrm{Co}=50 \mathrm{mg} / \mathrm{L} ; \quad \mathrm{pH}=6.5$, time $=120 \mathrm{~min}$, agitation speed $=250 \mathrm{rpm})$.

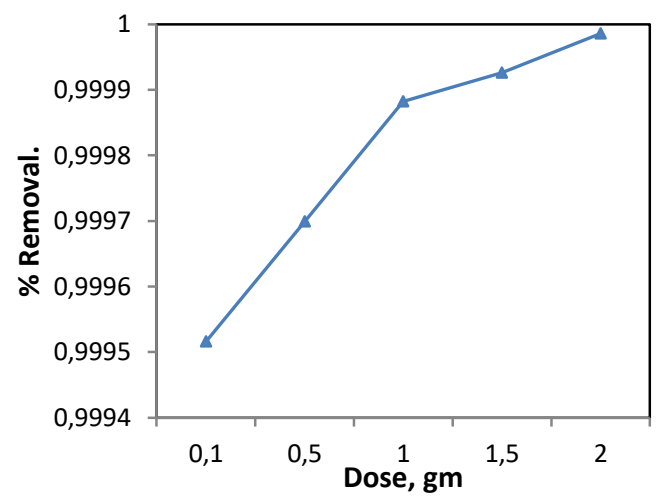

Fig. 8. Effect of alumina dosage on removal efficiencies of $\mathrm{Ag}^{+1} \quad(\mathrm{Co}=25 \mathrm{mg} / \mathrm{L} ; \mathrm{pH}=6.5$, time $=60 \mathrm{~min}$, agitation speed $=250 \mathrm{rpm}$ ). 


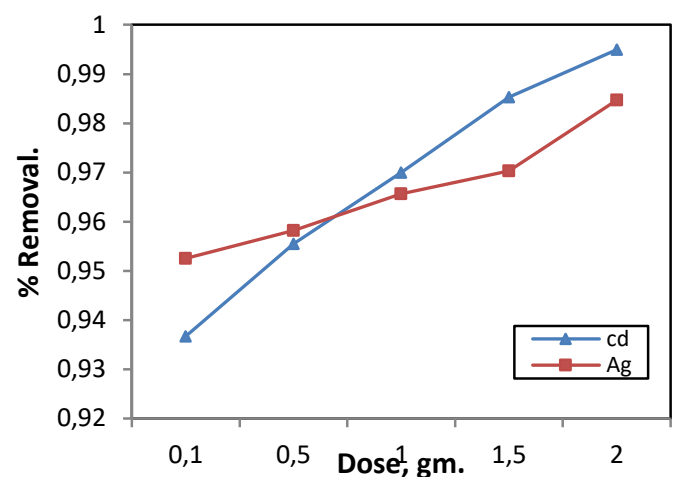

Fig. 9. Effect of alumina dosage in binary system of $\mathrm{Cd}^{+2}$ and $\mathrm{Ag}^{+1} \quad(\mathrm{Co}=50 \mathrm{mg} / \mathrm{L} ; \mathrm{pH}=6.5$; agitation speed $=250 \mathrm{rpm}$, time $=60 \mathrm{~min})$.

To investigate the effect of initial $\mathrm{Cd}^{+2}$ and $\mathrm{Ag}^{+1}$ concentration, the batch experiments were conducted at various concentration of metal from $(25$ to $200 \mathrm{mg} / \mathrm{L}$ ). Figures (10 to 12$)$ explains that the removal efficiency decreased inversely with increased the initial metal concentration. This plateau represents saturation of the active sites available on the alumina samples for interaction with metal ions. These results indicate that energetically less favorable sites become involved with increasing metal concentrations in the aqueous solution.

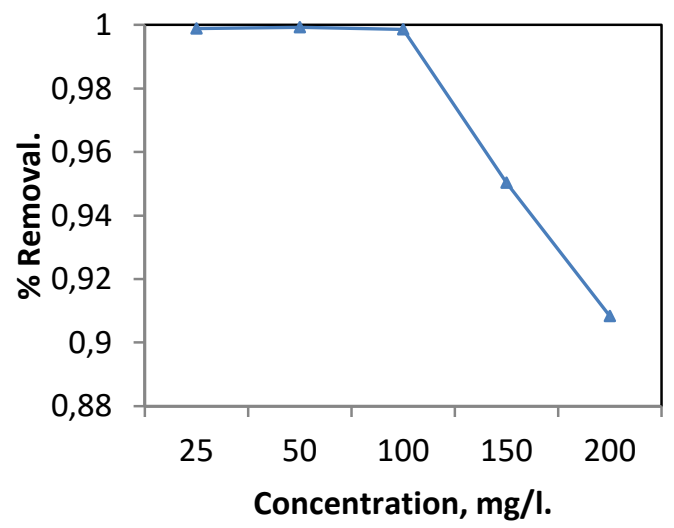

Fig. 10. Effect of initial concentration on removal efficiency of $\mathrm{Cd}^{+2}$ on alumina $(\mathrm{pH}=6.5$; dose $=2 \mathrm{gm} ; \quad$ agitation $\quad$ speed $=250 \mathrm{rpm}$ ,time $=120 \mathrm{~min}$ )

\subsection{Agitation speed}

The effect of agitation speed on removal efficiency of metal ions adopted here was studied by varying the speed of agitation from (50 to $250 \mathrm{rpm}$ ) and keeping other parameters equal to best ones obtained in the previous steps.
Figures (13 to 15 ) show that removal of $\mathrm{Cd}^{+2}$ and $\mathrm{Ag}^{+1}$ ions were increases with the increase in shaking rate. The results also indicate that a shaking with $250 \mathrm{rpm}$ is sufficient to ensure that all the surface binding sites are made readily available for metal uptake. These results can be associated to the fact that the increase in the agitation speed improves the diffusion of metal ions towards the surface of the reactive media. Thus, proper contact is developed between metal ions in solution and the binding sites, which promotes effective transfer of sorbet ions to the sorbent sites.

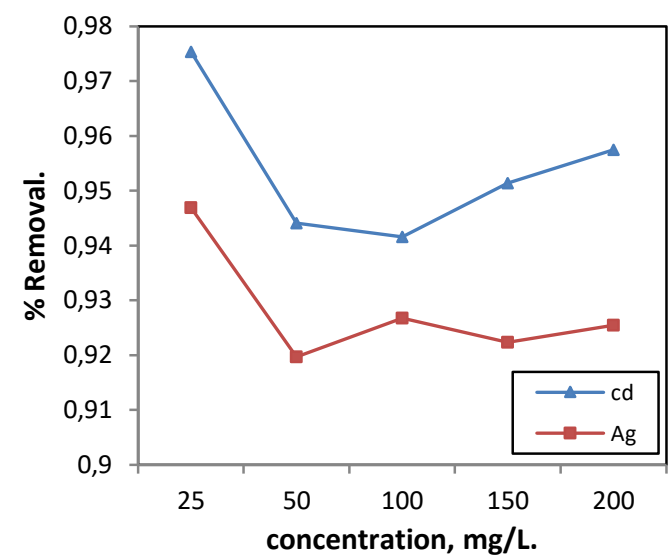

Fig. 11. Effect of initial concentration on removal efficiency of $\mathrm{Ag}^{+1}$ on alumina $(\mathrm{pH}=6.5$; dose $=2 \mathrm{gm} ; \quad$ agitation speed $=250 \mathrm{rpm}$ ,time $=60 \mathrm{~min})$.

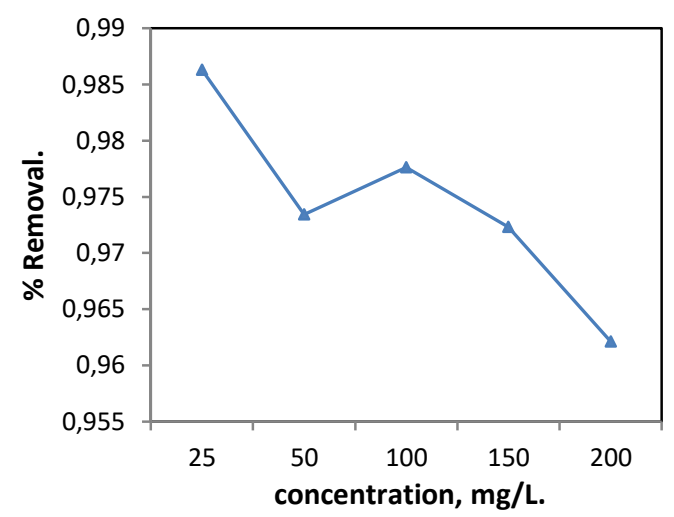

Fig. 12. Effect of initial concentration on removal efficiency in binary system of $\mathrm{Cd}^{+2}$ and $\mathrm{Ag}^{+1}$ on alumina $(\mathrm{pH}=6.5 ;$ dose $=2 \mathrm{gm}$ ;agitation speed $=250 \mathrm{rpm} ;$ time $=60 \mathrm{~min})$. 


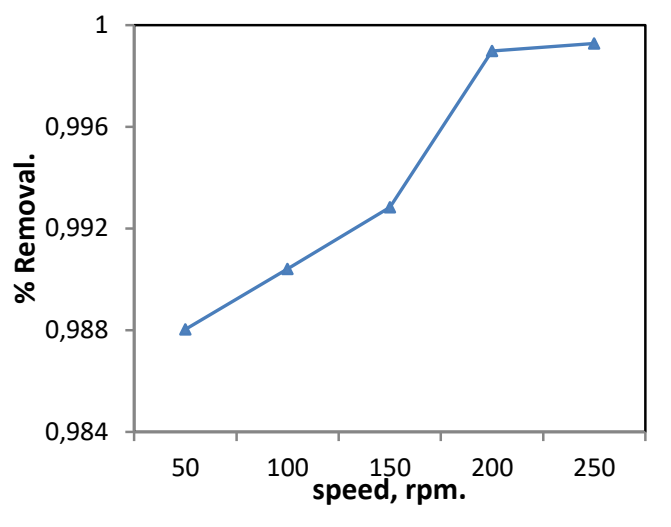

Fig. 13. Effect of agitation speed on percentage removal of $\mathrm{Cd}^{+2}(\mathrm{Co}=50 \mathrm{mg} / \mathrm{L}$; $\mathrm{pH}=6.5$, dose $=2 \mathrm{gm}$, time $=120 \mathrm{~min})$.

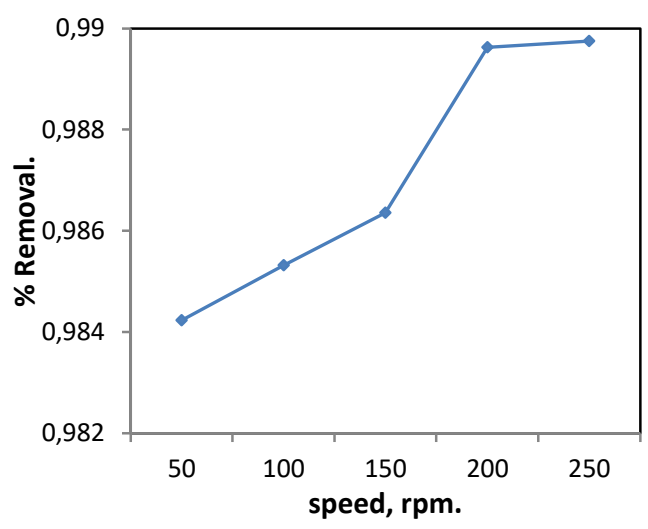

Fig. 14. Effect of agitation speed on percentage removal of $\mathrm{Ag}^{+1} \quad(\mathrm{Co}=25$ $\mathrm{mg} / \mathrm{L} ; \quad \mathrm{pH}=6.5, \quad$ dose $=2 \mathrm{gm}$, time $=60 \mathrm{~min}$ ).

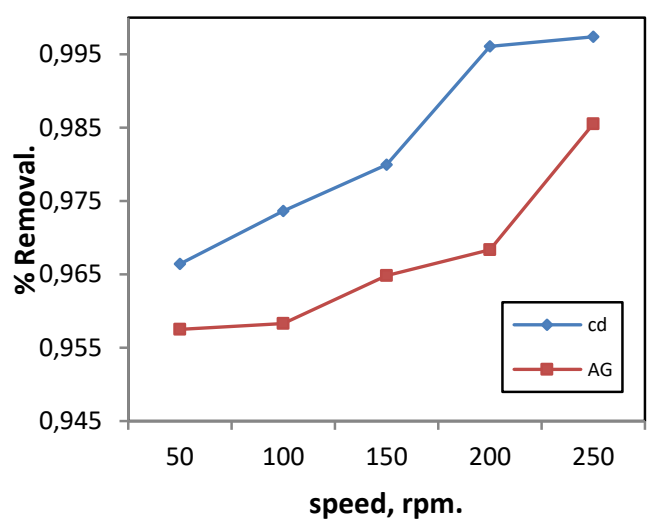

Fig. 15. Effect of agitation speed on percentage removal of metals in binary system $(\mathrm{Co}=25 \mathrm{mg} / \mathrm{L}, \mathrm{pH}=6.5$, time $=60 \mathrm{~min}$, dose $=2 \mathrm{gm})$.

\section{EXPERIMENTS}

The isotherm is represented by the linear plot of specific adsorption $\left(C_{e} / q_{e}\right)$ against the equilibrium concentration $\left(C_{e}\right)$. Figures (16 to 18) show that the adsorption obeys the Langmuir model. The Langmuir equation is represented by Jenan, et al.[9]:

$\mathrm{q}_{\mathrm{e}}=\frac{\mathrm{abC}_{\mathrm{e}}}{1+\mathrm{bC}_{\mathrm{e}}}$

And the equation may be linearized as:

$$
\frac{\mathrm{C}_{\mathrm{e}}}{\mathrm{q}_{\mathrm{e}}}=\frac{1}{\mathrm{a}} \mathrm{C}_{\mathrm{e}}+\frac{1}{\mathrm{ab}}
$$

The constants $\mathrm{b}$ and $\mathrm{q}_{\mathrm{e}}$ relate to the energy of adsorption and maximum adsorption capacity, and their values are obtained from the slope and interception of the plot and are presented in Table1. The Freundlich isotherm is an empirical equation that is very useful because it accurately describes much adsorption data. The Freundlich equation is represented by Jenan, et al. [9]:

$\mathrm{q}_{\mathrm{e}}=\mathrm{K}_{\mathrm{f}} \mathrm{C}^{1 / \mathrm{n}}$

The linear form of the equation obtained by taking the logarithm as follows:

$$
\log \mathrm{q}_{\mathrm{e}}=\log \mathrm{K}_{\mathrm{f}}+\frac{1}{\mathrm{n}} \log \mathrm{C}_{\mathrm{e}} \ldots(4)
$$

The Freundlich isotherm Figures (17 and 19) are introduced as an empirical model, where $q_{e}$ represents the amount adsorbed per amount of adsorbent at the equilibrium $(\mathrm{mg} / \mathrm{gm}), C_{e}$ represents the equilibrium concentration $(\mathrm{mg} / \mathrm{L})$, and $K_{f}$ and $n$ are parameters that depend on the adsorbate and adsorbent[Reed, and Matsumoto, 1993]. Freundlich equilibrium constants were determined from the plot of $\ln \mathrm{q}_{\mathrm{e}}$ versus $\ln \mathrm{C}_{\mathrm{e}}$. From Figures (17 and 19) on the basis of the linear form of Freundlich equation, the $n$ value indicates the degree of nonlinearity between solution concentration and adsorption as follows: if $n=1$, then adsorption is linear; if $<1$, then adsorption is a chemical process; if $n>1$, then adsorption is a physical process. The situation $n>1$ is most common and may be due to a distribution of surface sites or any factor that causes a decrease in adsorbent-adsorbate interaction with increasing surface density [10] 
and the values of $n$ within the range of $1-10$ represent good adsorption [11] [12]. In the present study, since $n=(1.92,1.91)$ for $\mathrm{Cd}^{+2}$ and $\mathrm{Ag}^{+1}$, respectively lies between 1 and 10 it indicates the physical adsorption of $\mathrm{Cd}^{+2}$ and $\mathrm{Ag}^{+1}$ ions onto alumina and represent favorable adsorption condition. In both cases, linear plots were obtained, which reveal the applicability of these isotherms on the ongoing adsorption process.

Figures (16 to 19) exhibit Langmuir and Freundlich plots, respectively, for the adsorption of $\mathrm{Cd}^{+2}$ and $\mathrm{Ag}^{+1}$ ions onto alumina, and different Langmuir and Freundlich constants and coefficient of determination $\left(R^{2}\right)$ derived from these plots are presented in Table 1. To find the most appropriate model for the $\mathrm{Cd}^{+2}$ and $\mathrm{Ag}^{+1}$ ions adsorption; data were fitted to Langmuir and Freundlich isotherm models. Results revealed that Freundlich adsorption isotherm was the best model for the $\mathrm{Cd}^{+2}$ and $\mathrm{Ag}^{+1}$ ions adsorption onto alumina with $R^{2}$ of 0.9657 and 0.9664 , respectively.

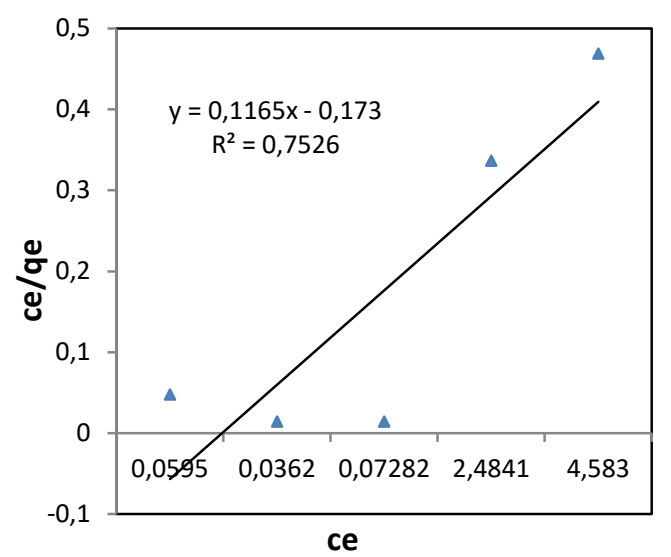

Fig. 16. Langmuir isotherm for sorption of $\mathrm{Cd}^{+2} \quad(\mathrm{pH}=6.5 ; \quad$ dose $=2 \mathrm{gm} ; \quad$ agitation speed $=250 \mathrm{rpm}$; contact time $=120 \mathrm{~min}$.).

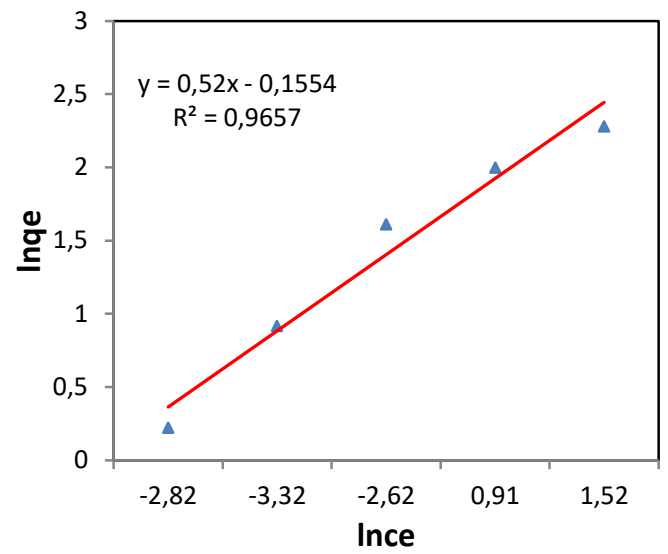

Fig. 17. Freundlich isotherm for sorption of $\mathrm{Cd}^{+2} \quad(\mathrm{pH}=6.5 ; \quad$ dose $=2 \mathrm{gm} ; \quad$ agitation speed $=250 \mathrm{rpm}$; contact time $=120 \mathrm{~min}$.).

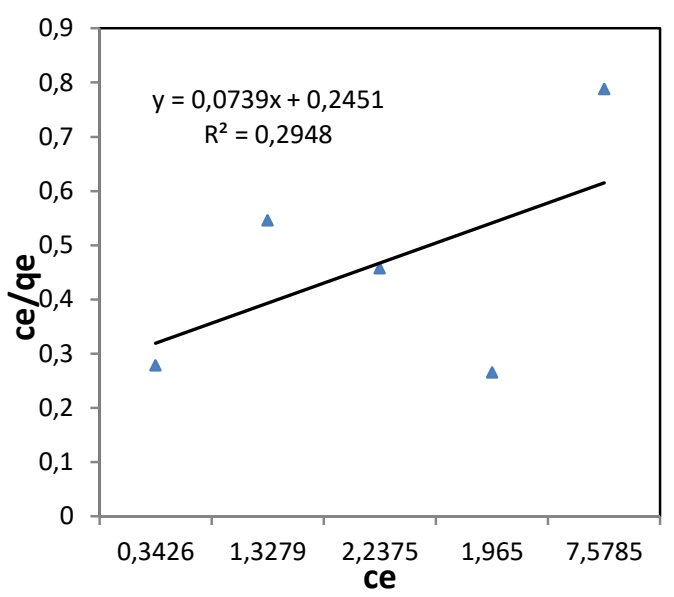

Fig. 18. Langmuir isotherm for sorption of $\mathrm{Ag}^{+1} \quad(\mathrm{pH}=6.5 ; \quad$ dose $=2 \mathrm{gm} ; \quad$ agitation speed $=250 \mathrm{rpm}$; contact time $=60 \mathrm{~min}$.).

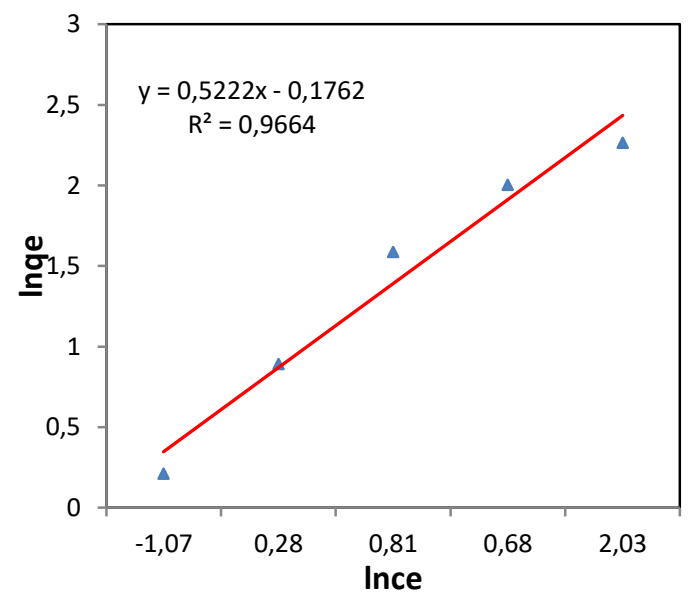

Fig. 19. Freundlich isotherm for sorption of $\mathrm{Ag}^{+1}(\mathrm{pH}=6.5$, dose $=2 \mathrm{gm}$, agitation speed $=250$ rpm, contact time $=60 \mathrm{~min}$.). 
Table 1: Sorption isotherm constants for cadmium and silver on alumina reactive material. It is clear that the Freundlich isotherm model provided the best correlation in compared with Langmuir isotherm model for $\mathrm{Ag}^{+1}$ and $\mathrm{Cd}^{+2}$ sorption on the alumina.

\begin{tabular}{|c|c|c|c|c|c|c|}
\hline \multirow{2}{*}{\begin{tabular}{c} 
壹 \\
\cline { 2 - 7 }
\end{tabular}} & \multicolumn{2}{|c|}{ Langmuir constants } & \multicolumn{3}{|c|}{ Freundlich constants } \\
\cline { 2 - 7 } & $\begin{array}{c}\mathrm{a}, \\
\mathrm{mg} / \mathrm{gm}\end{array}$ & $\begin{array}{c}\mathrm{b}, \\
\mathrm{L} / \mathrm{mg}\end{array}$ & $\mathrm{R}^{2}$ & $\begin{array}{c}\mathrm{K} \\
\mathrm{mg} / \mathrm{g} \\
\mathrm{m}\end{array}$ & $1 / \mathrm{n}$ & $\mathrm{R}^{2}$ \\
\hline $\mathrm{Cd}^{+2}$ & 8.583 & $\begin{array}{c}- \\
0.673\end{array}$ & 0.752 & 0.856 & 0.52 & $\begin{array}{c}0.9 \\
65\end{array}$ \\
\hline $\mathrm{Ag}^{+1}$ & $\begin{array}{c}13.531 \\
8\end{array}$ & 0.301 & 0.294 & 0.839 & 0.522 & $\begin{array}{c}0.9 \\
66\end{array}$ \\
\hline
\end{tabular}

\section{Conclusions}

The retention of $\mathrm{Cd}(\mathrm{II})$, and $\operatorname{Ag}(\mathrm{I})$ onto nano activated alumina has been carried out. Batch adsorption experiments were used for analyzing the effects of the following variables: such as concentration, adsorbent dosage, $\mathrm{pH}$, agitation speed and contact time. The \% of adsorption increases on changing the $\mathrm{pH}$ of the medium from acidic towards neutral. The time taken for attainment of equilibrium for all the metal ions has been established. The removal yield increases with increasing the adsorbent dosage, agitation speed and decreases with increase initial metal ion concentration. The effective removal of the heavy metal ions is mainly dependent on the ratio of adsorbent dosage to the concentration of metal ions, which is of course a compromise between cost effectiveness of the process and the desired retention percentage. The mathematical description for the adsorption behavior fit well to Freundlich isotherm model with good coefficient of determination.

\section{References}

1. Sharma Y. C., V. Srivastava, A. K. Mukherjee., 2010. Synthesis and Application of Nano-Al2O3 Powder for the Reclamation of Hexavalent Chromium from Aqueous Solutions. Department of Applied Chemistry, Institute of Technology, Banaras Hindu University, Varanasi-221005, India

2. Sharma Y.C., V. Srivastava, V.K. Singh, S.N. Kaul and C.H. Weng, 2008. Nano-adsorbents for the removal of metallic pollutants from water and wastewater. MIT College of Engineering, Kothrud, Pune, India.

3. Sheeba S., R. Rajkumar, 2013. Removal of Cr(VI), $\mathrm{Cu}(\mathrm{II}), \mathrm{Pb}(\mathrm{II})$ and $\mathrm{Ni}(\mathrm{II})$ from Aqueous Solutions by Adsorption on Alumina. India, Research Journal of Chemical Sciences, ISSN 2231-606X, Vol. 3(8), 44-48, Res. J. Chem. Sci.
4. Metcalf and Eddy, 2003. Ch.1Wastewater Engineering 4thed.

5. Tingyi L., Zhong-Liang W., Yanqiu S., 2015. Manipulating the morphology of nanoscale zerovalent iron on pumice for removal of heavy metals from wastewater. Laboratory of Water Resources and Environment, Tianjin Normal University, Tianjin 300387, China.

6. Omid R., Ahmad S., Mohammad R., 2012. New Method for Synthesis Nano Size $\gamma$-Al2O3 Catalyst for Dehydration of Methanol to Dim-ethyl Ether. International Journal of Chemical Engineering and Applications, Vol. 3, No. 2.

7. Rangsivek, 2010. Removal of dissolved metals from storm water runoff by zero-valent iron. Ph.D. thesis, University of Berlin.

8. Gao Z., T.J. Bandosz, Z. Zhao, M. Han, J. Qiu, 2009. Investigation of factors affecting adsorption of transition metals on oxidized carbon nanotubes. Journal of Hazard Material.

9. Jenan A., Asawer A., Ramzi H., Abbas H., 2014. Study the Feasibility of Alumina for the Adsorption of Metal Ions from Water. Chemical Engineering Department, College of Engineering, University of Baghdad, Baghdad, Iraqi Journal of Chemical and Petroleum Engineering, Vol.15 No.3, 37-50, ISSN: 1997-4884.

10. Reed, B.E., Matsumoto, M.R., 1993. Modeling cadmium adsorption by activated carbon using the Langmuir and Freundlich isotherm expressions". Separation Science and Technology,vol.28, no. 1314, pp. 2179-2195.

11. McKay, G., Blair, H.S., Gardner, J.R., 1982. Adsorption of dyeson chitin. Journal of Applied Polymer Science,vol.27,no.8, pp.3043-3057.

12. Ozer, A., Pirinc, H.B., 2006. The adsorption of $\mathrm{Cd}(\mathrm{II})$ ions on sulphuric acid-treated wheat bran. Journal of Hazardous Materials, vol.137, no.2, pp.849-855. 